\title{
Industrial policy, production efficiency improvement and the Chinese county economic growth $^{* 1}$
}

\author{
Wang Zhenhua ${ }^{2}$, Zhang Guangsheng ${ }^{3}$
}

\begin{abstract}
This study aims at analyzing the difference in the level of economic development between China's counties from the two perspectives of industrial policy and production efficiency. Based on panel data of 1830 Chinese counties, this study employs the new classical economic growth theory framework to analyze the counties' economic growth by the perpetual inventory method, Malmquist index, among others. The results show that the economy of the counties exhibits $\delta$ convergence since 2004, and the absolute differences in the different counties are expanding. Industrial policy ensures the additional deepening of the level of capital in the county. Additionally, a substantial difference was observed between the agricultural sector and the non-agricultural sector, whereby the total factor productivity and the technical efficiency are on the rise, resulting in the phenomenon of dual paths of technological progress. In summary, the capital deepening difference between the sectors, production efficiency, and dual paths of technological progress owing to the counties' industrial policy are the basic reasons for the regional differences in the level of economic development in China.
\end{abstract}

Key words: county economy, $\delta$ convergence, industrial policy, dual paths of technological progress

JEL classification: $C 25,011, O 13$

* Received: 23-10-2016; accepted: 09-12-2016

1 This work was supported by National Natural Science Foundation of China (No. 71503173, 71273179) and Social Science Foundation of Liaoning Province (No. L15CJY014).

2 PhD, Lecturer, College of Economics and Management, Shenyang Agricultural University, Shenyang 110866, China. Scientific affiliation: development economics, industrial policies. E-mail: wangzhenhuasy@yeah.net.

3 Professor, College of Economics and Management, Shenyang Agricultural University, Shenyang 110866, China. Scientific affiliation: development economics, industrial policies. E-mail: guangshengzhangsy@126.com.Phone:+8613674283521 (Corresponding author). 
Wang Zhenhua, Zhang Guangsheng • Industrial policy, production efficiency improvement...

\section{Introduction}

In line with the Chinese saying "A group of counties is/makes the country," the Chinese government has been focusing on the development of the county economy since the beginning of this century. The 18th National Congress presented proposals to promote the scientific development of the county economy. China's county economy, which accounted for $51.04 \%$ of the GDP and contributed a total of 24.14 trillion yuan by 2011, has made great achievements. On the other hand, a noteworthy phenomenon is that the differences in the levels of the development in county economy are growing. According to the new classical economic growth theory, the growth of the economy has two sources, one is the continuous accumulation of input elements (Barro, 1991; Seller and Millán, 2014; Yazdkhasti, 2015), and the second is the continuous improvement in the total factor productivity (Koop et al., 2000; Lucas and Robert, 1988). The key research questions proposed in this study are the following. How can the trend of factor accumulation and efficiency promotion in different counties be presented? What kind of a role has industrial policy played in these aspects? How has this trend affected the growth of the county economy? What are the differences in the level of development in the county economy?

In terms of the input elements of an economy, capital is the leading factor (King and Levine, 1994). Therefore, this study focuses on the capital deepening of the county economy and the capital deepening differences between industries, and explains the reason of capital deepening from the viewpoint of the industrial policy (Aghion et al., 2015). In addition, this study also focuses on improving the production efficiency of the county economy. The productivity is fragmented into technical efficiency and technological progress (Jorgenson and Griliches, 1967), and the difference in the progress of technology, that is, the phenomenon of the dual paths of technological progress, is discussed.

For the research of the stated problems, the following hypothesis has been set: capital deepening and efficiency upgrading are the prime reasons for the economic growth and the differences in the county economy in China. The industrial policy is responsible for the difference in capital deepening in the regions in China. The remainder of this study is organized as follows. Section 2 presents a brief review of the relevant literature. Section 3 describes the CobbDouglas production function and Translog model, details the perpetual inventory method and the Malmquist index. The descriptive statistics of the development of China's county economy is given by Section 4. Section 5 discusses the results. Last, Section 6 concludes. 


\section{Literature review}

The rapid growth and regional economic differences within China is a growing concern of many scholars (Ansar et al., 2016). The primary approach of the representative literature is that there is no overall convergence of China's economic development at the present stage (Barro, 2016); however, there are some areas of the club convergence. In the current stage of development, there is a "short-term divergence, and a long-term convergence" (Lin and Liu, 2003). In recent years, China's economic growth in the county has attracted the attention of many scholars. Due to the difficulty faced in conducting the counties' overall data collection, most of the empirical studies analyzed the counties within a specific region, while country-level studies were mainly qualitative analyses.

Consequently, individual scholars sorted out the country's county panel data to analyze the differences in the development of China's county economy along with the growth convergence, spatial interaction, and so on (Ke, 2009). The findings of the representative literature research mentioned above may be different along with the sample data; although they have all adopted a national level panel data analysis. However, these studies also include municipal districts' samples, considering the main city areas mainly comprise the metropolitan economy, while the difference in the county economy is larger, and thus, the sample heterogeneity may affect the conclusions (Ke, 2009). Although some studies analyzed the differences in the development of China's county economy using the counties' sample data, the number of samples per year differs (Chen et al., 2011). Representative literature established the following: economic growth in the county exists in the presence of significant steric interactions (Ke, 2009); differences in the development of the county economy in China continue to expand; moreover, there is a $\alpha$-divergence (Barro, 2016). However, some studies also show the existence of $\delta$ convergence in the China county economy (Chen et al., 2011).

In line with the new classical economic growth theory (Yang, 2011), the relevant research have begun to focus on the issue of the county factor inputs and production efficiency (Aghion et al., 2015). Capital elements, as a leading factor, have attracted the attention of scholars, whereby they have focused on the study of capital deepening and industrial policy (Jorgenson and $\mathrm{Vu}, 2016$ ). In recent years, in order to promote the county economic growth, the government formulated a series of industrial policies to guide capital inflow to the counties (Ke, 2009). From a development approach, the level of Chinese capital investment in the counties continues to grow to induce the counties to promote economic growth from the perspective of factor inputs. However, it should be noted that the existing policy differences between the counties could result in the growth of the county economy (Gourdon et al., 2016; Gorun et al., 2014). On the other hand, some scholars who have measured the efficiency of China's county economy reported a few disputes in the data, measurement methods, and measurement results. The scholars state 
that the economic development of the counties in the future will depend on the promotion of efficiency (Romer, 1990; Parente and Prescott, 1994; Olley and Pakes, 1996). Therefore, this study attempts to make a contribution by way of rearranging the county panel data. Moreover, based on the new classical growth theory (Lin, 2010), the study analyzes the economic growth and the difference in China's economy since the new century from the two aspects of the change in the factor input and the change in production efficiency, and elucidates the observations from the perspective of China's industrial policy. It is important to note that this study only follows the framework of the new classical economic growth theory to analyze the source of economic growth, and the relevant research conclusions are not based on the neoclassical growth theory, under strict assumptions.

\section{Methodology}

This research will follow the new classical economic growth theory analysis framework, from the point of view of the accumulation of input factors and the improvement of production efficiency, to analyze the source of China's county economic growth from two perspectives.

\subsection{Cobb-Douglas production function and Translog model}

This study assumes that the corporate production function has the form of a CobbDouglas production function:

$$
Y_{i, t}=F_{i, t}(A, K, L, \alpha, \beta),
$$

where $Y_{i, t}$ denotes the net output level (GDP) of county $i$ during period $t, K$ and $L$ denote the capital and labor inputs, respectively, and $\alpha$ and $\beta$ denote the output elasticity of capital and labor, respectively, $A$ denotes total factor productivity (TFP). As China's labor force has changed little, this study will analyze the source of China's county economic growth from two perspectives, which are capital deepening and total factor productivity.

Then we derive a Translog empirical equation from the Cobb-Douglas production function:

$$
\begin{aligned}
& \ln Y_{i, t}=\beta_{0}+\beta_{1} A_{i, t}+\beta_{2} \ln L_{i, t}+\beta_{3} \ln K_{i, t}+\beta_{4} A_{i, t}{ }^{2}+\beta_{5}\left(\ln L_{i, t}\right)^{2} \\
& +\beta_{6}\left(\ln K_{i, t}\right)^{2}+\beta_{7} A_{i, t} \ln L_{i, t}+\beta_{8} A \ln K_{i, t}+\beta_{9} \ln L_{i, t} \ln K_{i, t}+\varepsilon_{i, t}
\end{aligned}
$$

where $Y_{i, t}$ denotes the GDP of county $i$ during period $t, K_{i, t}$ and $L_{i, t}$ denote the capital and labor inputs of county $i$ during period $t$, respectively, respectively, $A_{i, t}$ denotes total factor productivity (TFP) of county $i$ during period $t$. 


\subsection{Coefficient of variation}

This study will first analyze the differences in the economic growth in the Chinese counties by using the coefficient of variation measurement method (Barro and Salai-Martin,1992), which is more commonly found in the literature. The calculation formula for the coefficient of variation is:

$$
C V=\sigma / \mu
$$

where the coefficient of variation is $C V$; standard deviation is $\sigma$; the mean is $\mu$.

\subsection{The perpetual inventory method}

In the perpetual inventory method, which is also commonly used in the literature, capital is used to represent stock data. The year 2000 has been taken as the base period, and the net fixed assets in 2010 have been used as the 2000 initial capital stock through the conversion price deflator. PIM argues that the stock of capital is the accumulation of the stream of past investments. This treatment can be expressed by the formula $K_{t}=\sum_{\tau=0}^{\infty} w_{\tau} I_{t-\tau}$, where $w_{\tau}$ denotes investing weight in period $t-\tau, I_{t-\tau}$ represents the amount of investment with constant price $t-\tau$. With a capital depreciation rate $\delta$, the capital stock in this paper can be expressed as $K_{t}=K_{t-1}(1-\delta)+\sum_{t-n} K_{t-n}$. Additionally, the depreciation rate of capital in the agricultural sector is assumed to be $11 \%$, and the non-agricultural sector capital depreciation rate is assumed to be $9.6 \%$.

\subsection{The Malmquist index}

This study will measure the production efficiency of the county economy and analyze the trend of the change. Some scholars have pointed out that the production efficiency of the production function based on the transcendental logarithmic production function is assumed a priori to determine the form of function production and the probability distribution of the random error term (Gong et al., 2015; Rios, http://xueshu.baidu.com/s?wd=author\%3A\%28CARLOS $\% 20$ D.\%20ACOSTA $\% 29 \% 20 \& t n=S E \_b a i d u x u e s h u \_c 1 g j e u p a \& i e=u t f-8 \& s c \_f$ para $=$ sc_hilight $\% 3$ Dperson2015). Therefore, this study establishes the input and output index system, and uses the Malmquist index to measure the change in the production efficiency of the county economy. The calculation of the Malmquist index is based on the formula (4) as follows:

$$
M o\left(X_{o}^{t}, Y_{o}^{t}, X_{o}^{t+1}, Y_{o}^{t+1}\right)=\left[\frac{\mathrm{D}_{o}^{t}\left(X_{o}^{t+1}, Y_{o}^{t+1}\right)}{\mathrm{D}_{o}^{\mathrm{t}}\left(X_{o}^{t}, Y_{o}^{t}\right)} \times \frac{\mathrm{D}_{o}^{t+1}\left(X_{o}^{t+1}, Y_{o}^{t+1}\right)}{\mathrm{D}_{o}^{t+1}\left(X_{o}^{t}, Y_{o}^{t}\right)}\right]^{1 / 2}
$$


where $M o\left(X_{o}^{t}, Y_{o}^{t}, X_{o}^{t+1}, Y_{o}^{t+1}\right)$ denotes Malmquist index, and $D_{o}^{t}\left(X_{o}^{t}, Y_{o}^{t}\right), D_{o}^{t}\left(X_{o}^{t+1}\right.$, $\left.Y_{o}^{t+1}\right), D_{o}^{t+1}\left(X_{o}^{t}, Y_{o}^{t}\right), D_{o}^{t+1}\left(X_{o}^{t+1}, Y_{o}^{t+1}\right)$ denote distance function. This study will not verbose on the specific principle. We will establish the input and output index system, and uses the Malmquist index to measure the change in the production efficiency of the county economy.

\subsection{Input-output index system}

We now measure the efficiency of the agricultural and non-agricultural sector in the county economy. With reference to output, the choice of indicators for the agricultural industry is the GDP and non-farm industry GDP.

The agricultural sector investment requires compliance with the three elements of the input hypothesis, which are the input indicators for land factors, labor factors, and capital elements. Among them, the quantitative indicators of land factors for cultivated land in the county, the labor quantity index number of rural workers in animal husbandry and fishery, and the relevant capital elements comprise the agricultural sector capital stock. The investment in the non-agricultural sector needs to comply with the two factors of the input hypothesis, including input indicators for the labor factor(incluthe number of employees) and capital factor; and the relevant capital elements constitute the capital stock of the non-agricultural sector.

\section{Empirical data and analysis}

\subsection{Data sources and processing}

At the end of 2010, the total number of Chinese units were fragmented into 2856 county-level administrative divisions, including 853 districts, 370 county-level cities, 1461 counties, 117 autonomous counties, and 52 Autonomous Banners, 2 special zones, 1 forest area. The scope of research of this article does not include the city area, which constitutes the remaining 2003 county-level units. The existing literature indicates that there was a turning point in China's GDP growth in 2002(Yuan, 2012), and the growth rate has been on a constant decline since then. Thus, the government proposed the "boost the county economy" policies in the same year. Taking into account the availability of data, the research period in this study is 2002 to 2011, which is a span of 10 years. The data have been gathered from the 2003-2012 China county (city) Social Economic Statistical Yearbook, which contains the national level data from all counties. In this paper, the original data were sorted and excluded as per the standards of the county level administrative division in 2010. Due to lack of data on the Tibet Autonomous Region and Shaanxi Province, the sample does not include these two provinces, which results in a total of 1820 counties. The missing data is supplemented by using the mean interpolation 
Wang Zhenhua, Zhang Guangsheng • Industrial policy, production efficiency improvement...

method and the trend regression method is used to supplement the data at both ends of the time period for more than two consecutive years.

This article collected and analyzed the nationwide Statistical Yearbook and the Statistical Yearbook of the various provinces to formulate a set of data on the integrity and authority of China's counties. It is necessary to note that the data range of this study, as of 2011, cannot be updated to 2015 because of which balanced panel data is used after simultaneously adjusting China's county administrative divisions and the statistical caliber.

\subsection{Descriptive statistics}

As the per capita GDP of China's counties increases, the relative standard deviation of the county level is also changing. Table A1 (in appendix) reports descriptive statistics results of per capita GDP of Chinese county economy. The standard deviation of per capita GDP of the county is increased from 4808.33 yuan in 2002 to 14499.96 yuan in 2010 .

Figure 1: China's county economic growth: 2002-2011 years

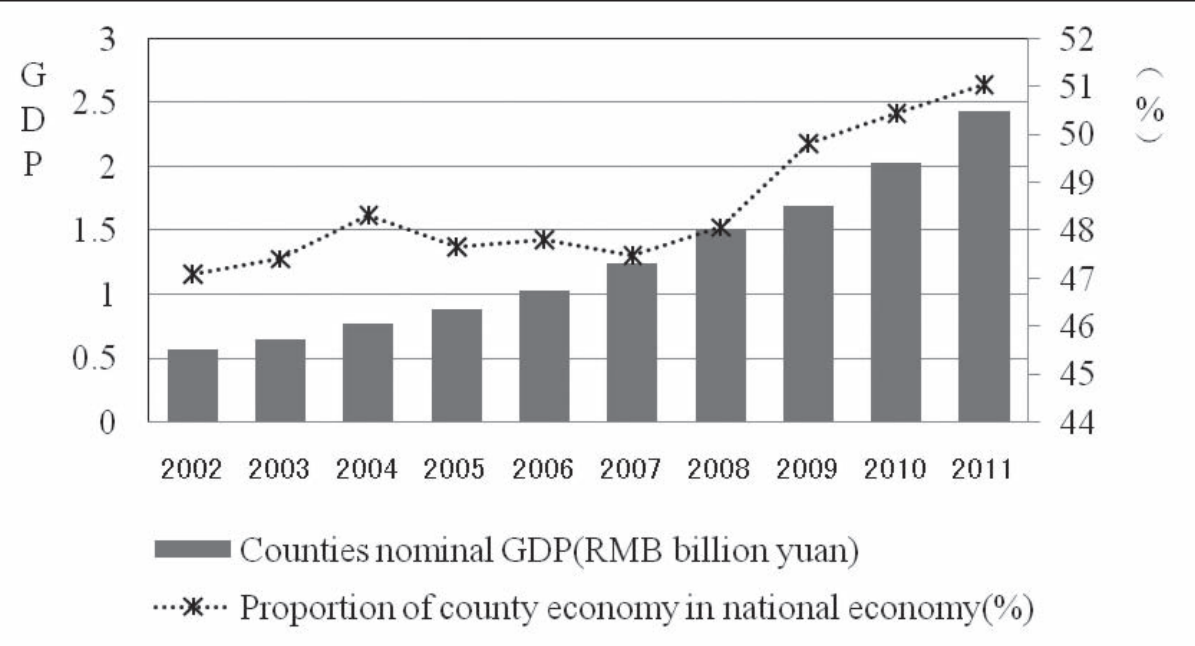

Source: Authors' calculation

Chinese county economy witnessed rapid development in the decade since 2002. The nominal GDP of the counties rose from 5.67 trillion yuan in 2002 to 24.14 trillion yuan in 2011, which is a twofold increase, compared with the average annual increase of $17.5 \%$, and is far higher than the overall growth of the national economy.

Similarly, in the past decade, the GDP of the national economy, as a whole, rose from $47.10 \%$ in 2002 to $51.04 \%$ in 2011 . In addition, since 2009 , the county 
economy began to account for more than half the GDP of the national economy, and the upward trend in the GDP contribution of China's counties is evident.

\subsection{The difference of the county economy growth in China}

China has a large number of counties and their level of development is uneven as per a study on the regional economic development level of the eastern, central, and western counties.

In this study, the eastern, central, and western counties are divided as follows: eastern counties, including Hebei, Liaoning, Jiangsu, Zhejiang, Fujian, Shandong, Guangdong, Hainan, and the other provinces and cities enclosed in 519 counties; central counties, including Shanxi, Jilin, Heilongjiang, Anhui, Jiangxi, Henan, Hubei, Hunan, and the other provinces under the jurisdiction of the 676 counties; counties in the western region, including Guangxi, Inner Mongolia, Chongqing, Sichuan, Guizhou, Yunnan, Gansu, Qinghai, Ningxia, Xinjiang, and the other provinces 625 counties. These three areas constituted a total of 1820 counties.

Figure 2: Counties economic growth in different regions



Source: Authors' calculation

In 2002, the county average of nominal GDP of the counties in the eastern areas reached 5.478 billion yuan, much higher than the central counties that touched 2.417 billion yuan and the 1.378 billion yuan reported in the western counties. By 2010, the eastern counties reached a nominal GDP figure of 19.702 billion yuan, which was higher than the 10.26 billion yuan of the western counties and the 14.834 billion yuan of the central counties. The absolute difference in the development level of the regions is gradually expanding. 
Wang Zhenhua, Zhang Guangsheng • Industrial policy, production efficiency improvement...

However, further analysis would be required to find the average annual growth rate of the nominal GDP of $17.35 \%$ in the eastern county in the period 2002-2010, the slightly higher nominal GDP of $18.57 \%$ in the central county, and slightly lower nominal GDP of $17.09 \%$ in the western counties. The relative difference between the central and eastern counties is owing to a slowly decreasing trend. The relative difference between the western counties and the central and eastern counties has not reduced.

\subsection{The $\delta$ convergence of China's county economic growth}

The quantitative indicators are calculated using the per capita GDP of the county as the coefficient of variation is determined using a cross section of the data from each year's calculations, which is a numerical process.

Figure 3: The difference of county economy in China and the difference between the east, central, and west regions

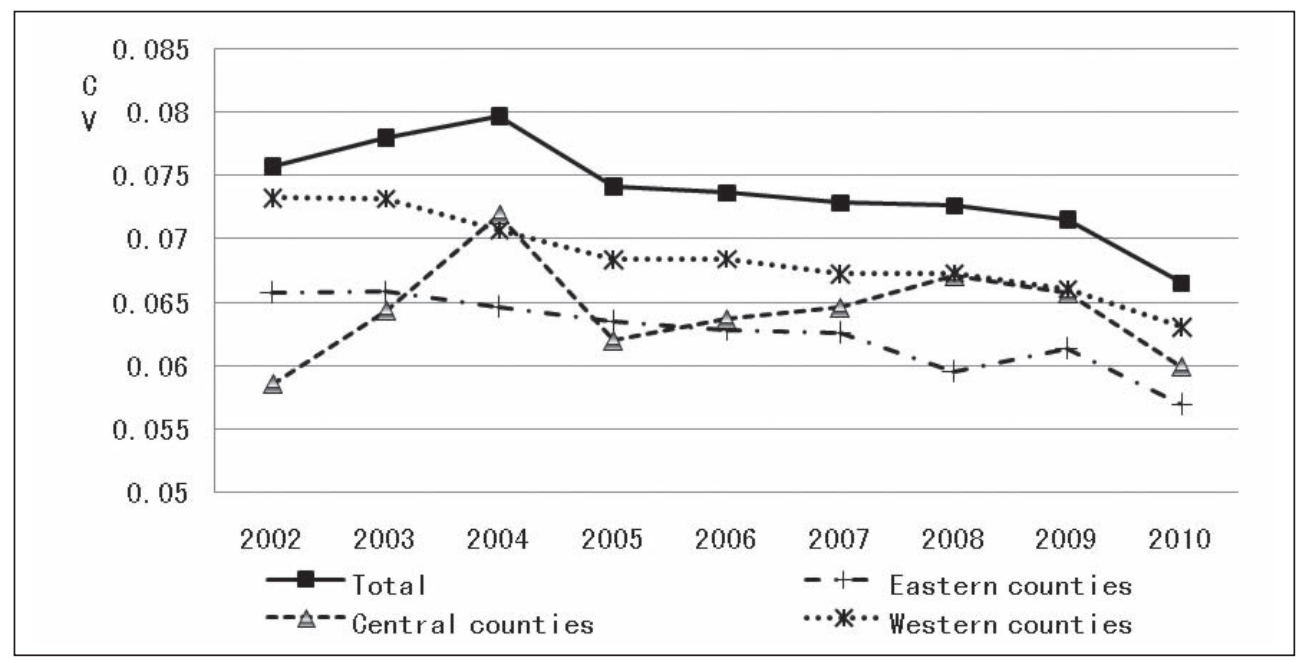

Source: Authors' calculation

On evaluating the variation coefficient, it can be observed that the differences in China's county-level economies did not decrease until the year 2004, when a $\delta$ convergence emerged and appeared to stabilize. However, the existing literature has not divided the regions to calculate further. Particularly, the fluctuations in the economic development of China's central counties were recorded. Generally, the productivity increases at approximately the same rate in the counties of eastern, central, and western China. However, the differences in the economy sizes results in the widening of quantitative gaps among regions, despite the $\delta$ convergence that exists since 2004, and its tendency toward maintaining stability in eastern and western China counties. 


\section{Results and discussion}

The above-mentioned Chinese county economy growth phenomenon is the result of the economic growth in each county's composition. On the other hand, according to the neoclassical growth theory, the factors of growth in all the counties' economy are the levels of investment and productivity.

\subsection{Results of Translog model}

The estimation results of Translog production function as well as data management are performed using software package STATA12.0. Table 1 documents the results of Translog production function regressions.

Table 1: The estimation results of Translog production function

\begin{tabular}{|l|r|r|r|}
\hline \multicolumn{1}{|c|}{ Variable } & Eastern counties & Central counties & \multicolumn{1}{c|}{ Western counties } \\
\hline$A$ & 0.0272 & $0.4162^{* * *}$ & -0.067 \\
\hline$A^{2}$ & 0.0009 & -0.001 & 0.0013 \\
\hline $\ln k$ & $-1.0070^{* * *}$ & $-0.5713^{*}$ & 0.202 \\
\hline $\operatorname{lnl}$ & $1.1401^{* * *}$ & $1.6547^{* * *}$ & $1.8372^{* * *}$ \\
\hline$(\operatorname{lnk})^{2}$ & $0.0842^{* * *}$ & $0.0670^{* * *}$ & $0.0614^{* * *}$ \\
\hline$(\operatorname{lnl})^{2}$ & 0.0141 & $-0.0309^{* * *}$ & $0.0252^{* *}$ \\
\hline $\operatorname{lnllnk}$ & $-0.0612^{* * *}$ & $-0.0806^{* * *}$ & -0.1295 \\
\hline Alnk & 0.0031 & -0.012 & $-0.0011^{* * *}$ \\
\hline Alnl & -0.0067 & $-0.0148^{* *}$ & $0.0091^{*}$ \\
\hline cons & $5.6043^{* * *}$ & $4.8562^{* *}$ & $-5.0737^{* * *}$ \\
\hline $\mathrm{R}^{2}$ within & 0.715 & 0.618 & 0.7678 \\
\hline $\mathrm{R}^{2}$ between & 0.8702 & 0.3926 & 0.8065 \\
\hline $\mathrm{R}^{2}$ overall & 0.8011 & 0.3945 & 0.773 \\
\hline sigma_u & 0.2972 & 0.7118 & 0.2312 \\
\hline sigma_e & 0.4159 & 0.3863 & 0.5519 \\
\hline rho & 0.338 & 0.7724 & 0.1493 \\
\hline Prob > F(/chi2) & 0.0000 & 0.0000 & 0.0000 \\
\hline
\end{tabular}

Note: ${ }^{* * *}$ Rejection of the null hypothesis of $1 \%$ significance levelt. ${ }^{* *}$ Rejection of the null hypothesis at the $5 \%$ significance level. ${ }^{*}$ Rejection of the null hypothesis of at the $10 \%$ significance level.

Source: Authors' calculation

The results confirm our hypothesis that capital deepening and efficiency upgrading are the prime reasons for the economic growth and the differences in the county 
economy in China. According to the new classical economic growth theory, the capital deepening and efficiency upgrading are the prime reasons for the economic growth.

\subsection{Industrial policy and its induced capital deepening and intersectoral differences}

To solve the lack of capital investment problems in the county's economic development, the government implemented a number of policies to promote capital inflows into the counties (Easterly et al., 1993). The specific policies for the counties included the reform of the financial institutions in the county by introducing a large number of financial outlets to provide low interest loans for investment projects (Zhang et al., 2004); the other related industrial policies promoted capital accumulation and capital deepening in the county. During the investigation period, the three elements of the Chinese county economy input levels were on the rise; however, the rate of growth was different. Capital investment, the leading factor, increased by $191.28 \%$, nearly a threefold increase, in the year 2003 . Overall, the rate of increase of the capital factor was the highest, while the labor factor and land factor rose slowly.

With regard to regions, the county industrial policy concentrated their efforts in the eastern region. Moreover, since both the central and eastern counties are larger than the western counties, it showed a decreasing level of the capital factor in all the counties. The capital investment level is the highest in the eastern county, and the growth of capital is the fastest (3.78 times) in the central county, in the period of 2003-2010. The growth rates of the regions in the west counties are higher than the growth rate of the capital element in the regions of the eastern counties.

The biggest characteristic of the county economic factor input is the constant growth in the capital investment. Moreover, the capital elements in the allocation between the sectors are also greater. The capital share of the county average agricultural sector declined to less than $30 \%$. This study further analyzes the county economy with reference to capital deepening and differences between sectors.

This article uses the capital per labor to measure the degree of capital deepening. Table A2 (in appendix) documents the trend of capital deepening in the county economy of China. During inspection period, the capital deepening degree of China's county economy was on a rise, and showed a trend of the accelerating trend of deepening. The agricultural sector's average annual capital deepening rate was $8.81 \%$, while the non-agricultural sector capital deepening rate was higher, reaching $21.89 \%$ Based on the regional correlation, the rate of capital deepening of the central counties was the highest, followed by the eastern counties, and the lowest rate of capital deepening was observed in the western counties. These three 
Wang Zhenhua, Zhang Guangsheng • Industrial policy, production efficiency improvement...

areas showed a trend of deepening acceleration, and the rate of capital deepening in the non-agricultural sector was higher than the agricultural sector.

Concerning the reality of the development of the county economy, the current policy is still tilted toward the non-agricultural industry, which is related to the characteristics of the agricultural industry. Due to the lack of collateral and the existence of information asymmetry, the relevant financial institutions would not opt to invest in the agricultural sector, and more capital would be invested in the non-farm sector, while the counties would continue investing in the process of development. Since the related investment projects are mostly non-agricultural, the relevant support policies by the government will be inclined toward the nonagricultural sectors, leading to more capital allocation.

\subsection{The efficiency of China's county economic growth and dual paths of technological progress}

This section will measure the productivity of the county economy based on the output-oriented model. The DEAP2.1 software was used in the process of the measurement of data to analyze trends.

The measurement results of the Malmquist index showed in Table A3 (in appendix) that the production efficiency of China's county economy continued to rise during the observation period, with an average annual growth rate of $6.48 \%$. The technical efficiency of the county's economic contribution was observed to be larger, showing an increase of $6.29 \%$. This gap in the index could be due to the establishment of high production efficiency in the eastern counties, which gave rise to a slowdown. Consequently, the trend of convergence was observed in the regional production efficiency of the three counties. The technological progress change index of the eastern counties is greater than 1 , which means that the eastern counties are mainly on the surface of the efficient frontier of the current Chinese county economy. As the change of production efficiency mainly depends on the continuous approach to the production frontier. The change in the production efficiency of the central and western counties is mainly due to the introduction of catch-up technologies.

Many scholars have noted that an economy should make full use of its comparative advantage by selecting the appropriate technology to achieve the production (Basu and Weil, 1998). However, this mainly entails analyzing the overall technological progress of backward economies and not as per the choices of different technical departments. Every economy has different industries and sectors; thus, the factor endowment structure determines the comparative advantage of different industries, which aids us in choosing different types of technology, that is, dual paths of technological progress. 
Table A4 (in appendix) documents the comparison of production efficiency of China's county region and department. The agricultural sector in the eastern counties of China enjoys higher productivity than the non-agricultural sectors. Productivity growth, in this region, is realized through technological advances in the agricultural sector and by efficiency increase in the non-agricultural sectors, wherein the threats to productivity would be neutralized by an increase in technical efficiency. In the central counties of China, however, both the agricultural and non-agricultural sectors witness higher productivity than those in the eastern counties of China, although productivity growth is also achieved by technological advances in the agricultural sector and by growth in technical efficiency in the non-agricultural sector. As regards to the western counties in China, the productivity in the agricultural and non-agricultural sectors grows at approximately the same rate. Agricultural technology, in the western region, develops slower than those in the eastern or central regions of China, while technical efficiency increases along with technological advancement. Generally, China's county-level economies are witnessing disparities, or "splits" in productivity growth, which is driven by the technological progress in the agricultural sector and the increase in the technical efficiency in the non-agricultural sector.

This study explains that the dual paths of technological progress in county economy is according to the theory of comparative advantage, wherein the county-level agricultural sector would adopt labor-intensive technologies to fully employ its resource elements and update such technologies at a quicker pace. Although modern agriculture also adopts technology and capital, they only account for a smaller portion than the resources employed in the non-agricultural sectors. The agricultural sector at the county levels could also choose technologies that are comparatively capitalintensive and remain updated on the technologies that are mechanical, informational, or electrical, as well as information on pesticides. Furthermore, despite rapid progress in agricultural technologies, there are issues, including overdose of fertilizer, Extensive management of some areas or seasons that affects technical efficiency. Therefore, the agricultural sector could rely on the technological advances to improve productivity. Non-agricultural sectors at the county level also have the comparative advantage of labor-intensive techniques, unlike those in the urban areas that have a high requirement of capital size and skilled labor, which makes it difficult to transfer to the counties. However, capital investment could be intensified in the counties to produce economies of scale, and thereby increase technical efficiency.

\section{Conclusion}

The presented results of the curried out analysis proved the hypothesis that capital deepening and efficiency upgrading are the prime reasons for the economic growth and the differences in the county economy in China, and the industrial policy is responsible for the difference in capital deepening in the regions in China. This 
Wang Zhenhua, Zhang Guangsheng • Industrial policy, production efficiency improvement...

study attempts to explain the rationale behind the difference in the county economic development level in China. The study establishes the internal reasons for the economic growth and the difference in the county economy in China. The study not only found that the absolute difference in the Chinese county development level is gradually expanding and that industrial policy leads to faster capital deepening, but it also exhibited great differences between sectors and the existence of the dual paths of technological progress of the county economy in the agricultural and the non-agricultural sector. The study provides new empirical evidence for the new classical economic growth theory and a new research experience for a follow-up study. The limitations of the empirical analysis are primarily related to the data availability. Because of the policy complexity of different regions in China, we have not analyzed the influence of the other regional policies on the county economy. Due to the availability of the micro data, the empirical analysis has not been carried out on the micro level. For the future research, the following directions can be stated: further in-depth analysis to discuss the existence of the Chinese County counties in the presence of $\delta$ convergence; further analysis of the reasons for the existence of the dual paths of technological progress in ensuring county production efficiency. Policy implications of the above findings include the following: First, innovation and the introduction of production technology are suitable for different counties and departments. Attention must be paid to improving the technical efficiency and reducing the extensive use of elements in the agricultural sector, while introducing suitable policies for smallscale production, labor intensive production, and other such characteristics of production technology in the industrial and services sectors. Second, guarantee the supply of capital elements and continue to strengthen the financial services provision to the county economy. Third, the government's policy for the counties should maintain a balance between support to the agricultural and nonagricultural sectors, promoting more capital to flow to the agricultural sector.

\section{References}

Aghion, P. et al. (2015) "Industrial policy and competition", American Economic Journal: Macroeconomics, Vol. 7, No. 4, pp.1-32, doi: 10.2139/ssrn.1811643.

Ansar, A., Flyvbjerg, B., Budzier, A., Lunn, D. (2016) "Does infrastructure investment lead to economic growth or economic fragility? Evidence from China", Oxford Review of Economic Policy, Vol. 32, No. 3, pp. 360-390. doi: 10.1093/oxrep/grw022.

Barro, R. J. (1991) "Economic Growth in a Cross Section of Countries", Quarterly Journal of Economics, Vol. 106, No. 2, pp. 407-443, doi: 10.3386/w3120.

Barro, R.J., Sala-i-Martin, X. (1992) "Convergence”, Journal of Political Economy, Vol. 100, No. 2, pp. 223-251, doi: 10.1086/261816. 
Barro, R. J. (2016) "Economic Growth and Convergence, Applied Especially to China", National Bureau of Economic Research, No. 21872, doi: 10.3386/ w21872.

Basu, S., Weil, D. N. (1998) "Appropriate Technology and Growth", Quarterly Journal of Economics, Vol. 113, No. 4, pp. 1025-1054, doi: 10.3386/w5865.

Chen, F., Long, Z., Lin, G. (2011) "An empirical study on economic disparity and convergence across China's counties", Journal of Yunnan University of Finance and Economics, Vol. 6, pp. 49-55.

Easterly, W., Kremer, M., Pritchett, L., Summers, L. (1993) "Good Policy or Good Luck? Country Growth Performance and Temporary Shocks", Journal of Monetary Economics, Vol. 32, No. 3, pp. 459-483, doi: 10.3386/w4474.

Gong, D., Liu, S., Lu, X. (2015) "Modelling the impacts of resource sharing on supply chain efficiency", International Journal of Simulation Modelling, Vol. 14, No. 3, pp.744-755, doi: 10.2507/ijsimm14(4)co20.

Gorun, A., Niculescu, G., Todorut, A. V., Rogojanu, D. C. (2014) "New Models and Modern Instruments in the Development of Social Services", Revista de Cercetare si Interventie Sociala, Vol. 45, pp. 240-252.

Gourdon, J., Monjon, S., Poncet, S. (2016) "Trade policy and industrial policy in China: What motivates public authorities to apply restrictions on exports?", China Economic Review, Vol. 40, No. 9, pp. 105-120, doi: 10.1016/j. chieco.2016.06.004.

Jorgenson, D. W., Vu, K. M. (2016) "The ICT revolution, world economic growth, and policy issues", Telecommunications Policy, Vol. 40, No. 5, pp. 383-397, doi: 10.1016/j.telpol.2016.01.002.

Jorgenson, D.W., Z. Griliches. (1967) "The Explanation of Productivity Change", Review of Economic Studies, Vol. 34, No. 3, pp. 249-283, doi: $10.2307 / 2296436$.

Ke, S. Z. (2009) "Spread-backwash and market area effects of urban and regional growth in china", Economic Research Journal, Vol. 8, pp. 85-98, doi: 10.110930.267419 .

King, R.G., Levine, R. (1994) "Capital Fundamentalism Economic Development and Economic Growth", Carnegie-Rochester Conference Series on Public Policy, Vol. 40, No. 6, pp. 259-292, doi: 10.1016/0167-2231(94)90011-6.

Koop, G., Osiewalski, J., Steel, M. F. J. (2000) "Modeling the Sources of Output Growth in a Panel of Countries", Journal of Business and Economic Statistics. Vol. 18, No. 3, pp. 284-299, doi: 10.2307/1392262.

Lin, Y. F., Liu, P. L. (2003) "Chinese Develop Strategy and Economic Convergence", Economic Research Journal, Vol. 3, pp. 19-25.

Lin, Y. F. (2010) "New structural economics: reconstructing the framework of development economics", China Economic Quarterly, Vol. 10, No. 1, pp. 1-32. 
Lucas, R. E., Robert, E. (1988) "On the Mechanics of Economic Development", Journal of Monetary Economics, Vol. 22, No. 1, pp. 3-42, doi: 10.1016/03043932(88)90168-7.

Olley, G. S., Pakes, A. (1996) "The Dynamics of productivity in the Telecommunications Equipment Industry", Econometrica, Vol. 64, No. 6, pp. 1263-1297, doi: 10.3386/w3977.

Parente, S. L., Prescott, E. C. (1994) "Barriers to Technology Adoption and Development", Journal of Political Economy, Vol. 102, No. 2, pp. 298-321, doi: $10.1086 / 261933$.

Romer, P. (1990) "Endogenous Technological Change", Journal of Political Economy, Vol. 98, No. 5, pp. 71-102, doi: 10.3386/w3210.

Rios, C.I.D.L., Herrera, R.A.T., Guillén, T. J. (2015) "Complexity in project management: analysis from the conceptual model working with people". Dyna, Vol. 90, pp. 23-23, doi: 10.6036/7124.

Seller, E. P., Millán, M. S. (2014) "Analysis and Impact of the Economic Crisis and Regulatory Changes in the Needs and Benefits System Municipal Social Services: Analysis Case of Murcia”, Revista de Cercetare si Interventie Sociala, Vol. 47, pp. 7-31.

Yang, B. (2011) "A review of the unified growth theory and its application", Management World, Vol. 11, pp. 149-156.

Yazdkhasti, M., Pourreza, A., Pirak, A., Abdi, F. (2015) "Unintended Pregnancy and Its Adverse Social and Economic Consequences on Health System: A Narrative Review Article", Iranian Journal of Public Health, Vol. 44, No. 1, pp. 12.

Yuan, F. H. (2012) "Structural accelerating and structural decelerating in the long run growth: an exposition", Economic Research Journal, Vol. 3, No. 1, pp. 127-139.

Zhang, J., Wu, G., Zhang J. (2004) "The estimation of China's provincial capital stock: 1952-2000”, Economic Research Journal, Vol. 10, No. 1, pp. 35-44. 


\title{
Industrijska politika, unapređivanje proizvodne učinkovitosti i gospodarski rast kineskih okruga ${ }^{1}$
}

\author{
Wang Zhenhua ${ }^{2}$, Zhang Guangsheng ${ }^{3}$
}

\begin{abstract}
Sažetak
Cilj ovog rada je analizirati razliku u stupnju gospodarskog razvoja među kineskim okruzima iz dvije perspektive: industrijske politike i proizvodne učinkovitosti. Temeljem panel podataka 1830 kineskih okruga, ovaj rad primjenjuje novi okvir klasične teorije gospodarskog rasta za analizu pomoću metode neprestanog inventara i Malmquist indeksa. Rezultati pokazuju da u okruzima prevladava delta konvergencija od 2004. godine, te da se apsolutna razlika širi u različitim okruzima. Industrijska politika osigurava dodatno produbljivanje razine kapitala u kantonu. Nadalje, značajna razlika je zabilježena između poljoprivrednog sektora $i$ nepoljoprivrednog sektora, pri čemu je ukupna faktorska produktivnost i tehnička učinkovitost u porastu što rezultira pojavom dvojnog puta tehnološkog napretka. Ukratko, zahvaljujući industrijskoj politici okruga, razlika u visini kapitala produbljuje razliku u sektorima, proizvodnoj učinkovitosti i dvojnom putu tehnološkog napretka što su temeljni razlozi regionalnih razlika u razini gospodarskog razvoja $u$ Kini.
\end{abstract}

Ključne riječi: gospodarstvo okruga, $\delta$ konvergencija, industrijska politika, dvojni put tehnološkog napretka

JEL klasifikacija: C25, O11, O13

1 Ovaj rad ima financijsku potporu kineske zaklade National Natural Science Foundation of China (No. 71503173, 71273179) and Social Science Foundation of Liaoning Province (No. L15CJY014).

2 Doktor ekonomskih znanosti, predavač, College of Economics and Management, Shenyang Agricultural University, Shenyang 110866, Kina. Znanstveni interes: razvojna ekonomija, industrijska politika.E-mail: wangzhenhuasy@yeah.net.

3 Profesor, College of Economics and Management, Shenyang Agricultural University, Shenyang 110866, Kina. Znanstveni interes: razvojna ekonomija, industrijska politika. E-mail: guangshengzhangsy@126.com.Tel.: +8613674283521 (autor za korespodenciju). 

Wang Zhenhua, Zhang Guangsheng • Industrial policy, production efficiency improvement... Zb. rad. Ekon. fak. Rij. • $2016 \cdot$ vol. $34 \cdot$ no. $2 \cdot 505-528$

\section{Appendices}



Wang Zhenhua, Zhang Guangsheng • Industrial policy, production efficiency improvement...

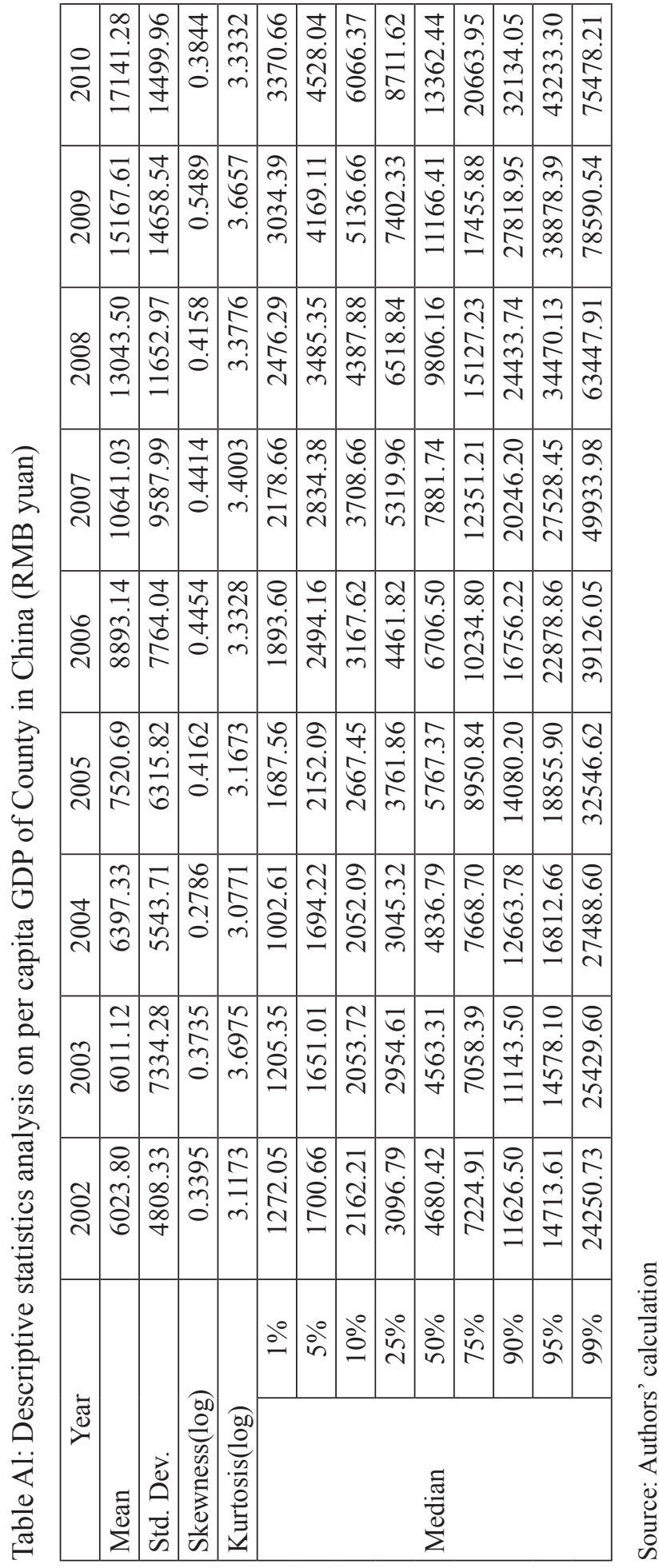


Wang Zhenhua, Zhang Guangsheng • Industrial policy, production efficiency improvement...

范

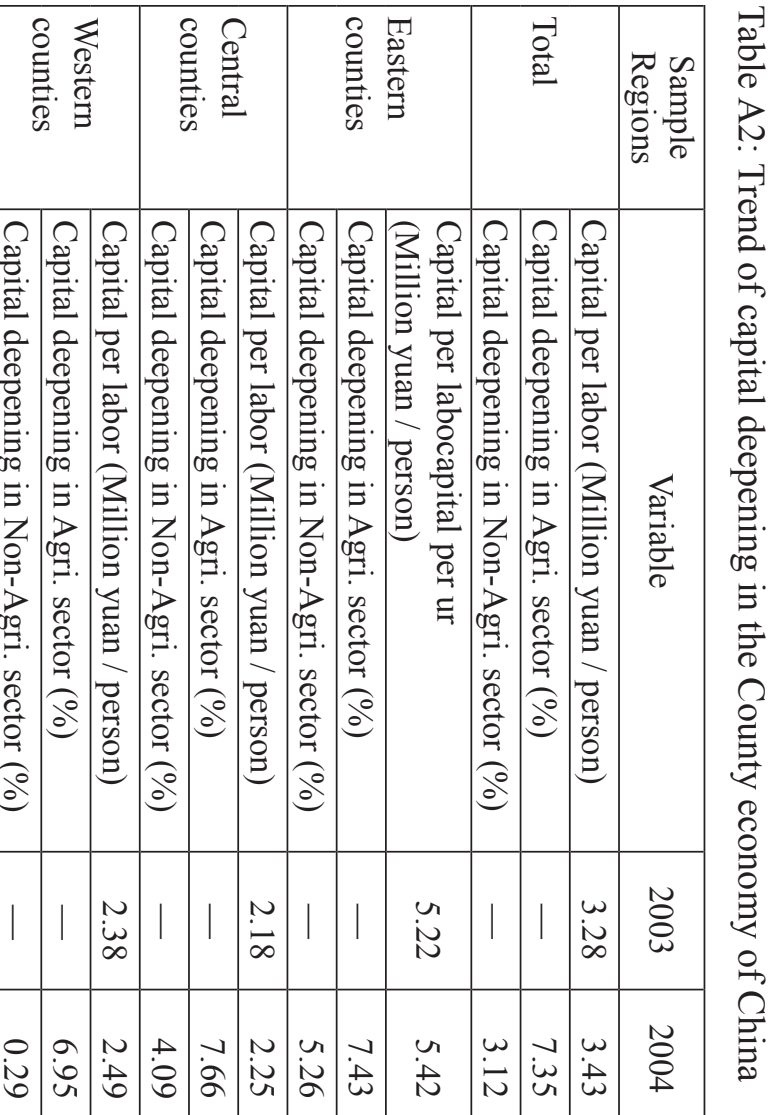

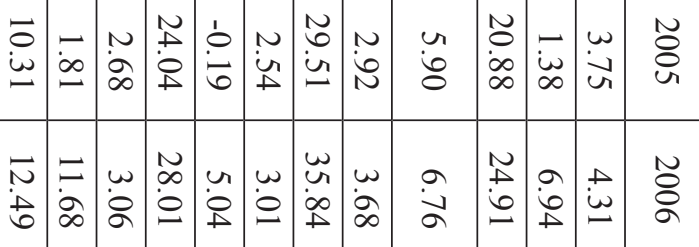



\begin{tabular}{|c|c|c|c|c|c|c|c|c|c|c|c|}
\hline in & $\begin{array}{l}\omega \\
\omega \\
\omega\end{array}$ & \begin{tabular}{l}
$N$ \\
Vi \\
\cline { 1 - 1 }
\end{tabular} & $\begin{array}{l}\overrightarrow{0} \\
\dot{\omega} \\
0\end{array}$ & 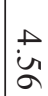 & $\begin{array}{l}\tilde{N} \\
\dot{N} \\
\tilde{\alpha}\end{array}$ & 范 & $\underset{\omega}{\infty}$ & $\begin{array}{l}\omega \\
\omega \\
\sigma\end{array}$ & $\stackrel{v}{a}$ & $\begin{array}{l}\dot{y} \\
\dot{\sigma}\end{array}$ & $\stackrel{N}{\circ}$ \\
\hline $\begin{array}{l}N \\
\text { vo }\end{array}$ & $\stackrel{\Delta}{\dot{\phi}}$ & $\begin{array}{l}\omega \\
\alpha \\
\dot{\alpha}\end{array}$ & $\begin{array}{l}\vec{u} \\
\dot{\sim}\end{array}$ & ì & $\mid \begin{array}{l}\tilde{N} \\
\alpha \\
w \\
y\end{array}$ & $\vec{u}$ & نo & $\begin{array}{l}\text { No } \\
6 \\
6\end{array}$ & $\ddot{\infty}_{\infty}$ & $\begin{array}{l}\sim \\
\dot{N}\end{array}$ & $\begin{array}{l}\text { 용 } \\
\text { O }\end{array}$ \\
\hline $\begin{array}{l}N \\
N \\
N\end{array}$ & $\stackrel{0}{\circ}$ & $\begin{array}{l}\mathbf{N} \\
\stackrel{\infty}{N} \\
N\end{array}$ & $\begin{array}{l}\vec{\sim} \\
\stackrel{\circ}{\circ}\end{array}$ & $\underset{\infty}{\infty}$ & 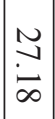 & $\stackrel{\vec{A}}{\dot{\vec{b}}}$ & $\stackrel{\vec{N}}{\stackrel{N}{N}}$ & $\begin{array}{l}N \\
i \\
\sigma\end{array}$ & $\underset{\infty}{\infty}$ & $\begin{array}{l}\infty \\
\infty \\
\infty\end{array}$ & $\stackrel{\widetilde{O}}{\stackrel{0}{0}}$ \\
\hline
\end{tabular}


Wang Zhenhua, Zhang Guangsheng • Industrial policy, production efficiency improvement...

\begin{tabular}{|c|c|c|c|c|c|c|c|c|c|c|c|c|}
\hline 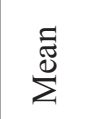 & 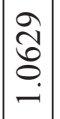 & $\begin{array}{c}\infty \\
\\
8 \\
-\end{array}$ & \begin{tabular}{c}
$\infty$ \\
\multirow{J}{0}{} \\
0 \\
-
\end{tabular} & 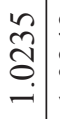 & 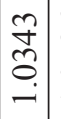 & $\begin{array}{l}0 \\
0 \\
\infty \\
0 \\
0 \\
-1\end{array}$ & $\begin{array}{c}\infty \\
6 \\
0 \\
0 \\
-\end{array}$ & 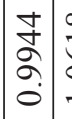 & 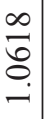 & 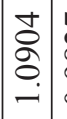 & $\begin{array}{l}\hat{N} \\
\infty \\
\vdots \\
0\end{array}$ & $\frac{n}{1}$ \\
\hline$\stackrel{\circ}{\stackrel{ }{\circ}}$ & $\begin{array}{l}2 \\
\text { ஸิ } \\
0 \\
-1\end{array}$ & $\begin{array}{l}\infty \\
\\
\varnothing \\
\end{array}$ & 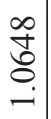 & 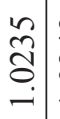 & 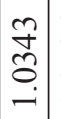 & $\begin{array}{l}0 \\
\infty \\
\infty \\
0 \\
-1\end{array}$ & \begin{tabular}{l}
$\infty$ \\
\multirow{6}{0}{} \\
$\vdots$ \\
-
\end{tabular} & 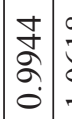 &  & 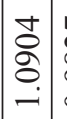 & $\begin{array}{l}\hat{N} \\
\infty \\
0 \\
0\end{array}$ & $\frac{n}{5}$ \\
\hline ஓి & $\left|\begin{array}{l}\vec{b} \\
\tilde{a} \\
0\end{array}\right|$ & $\begin{array}{l}n \\
\tilde{\sigma} \\
-\end{array}$ & \begin{tabular}{l}
0 \\
\multirow{2}{*}{} \\
\\
0
\end{tabular} & $\begin{array}{c}0 \\
\infty \\
\infty \\
\infty \\
0 \\
0\end{array}$ & 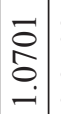 & $\begin{array}{l}\mathfrak{d} \\
\delta \\
\vdots \\
0 \\
0\end{array}$ & $\left|\begin{array}{l|}\infty \\
0 \\
\vdots \\
\vdots \\
0\end{array}\right|$ & $\mid \begin{array}{l}\vec{\infty} \\
\dot{0} \\
\dot{-}\end{array}$ & $\begin{array}{l}\tilde{c} \\
\infty \\
\tilde{\sigma} \\
0\end{array}$ & $\begin{array}{c}0 \\
1 \\
\infty \\
0 \\
0 \\
0\end{array}$ & $\begin{array}{l}\hat{a} \\
\infty \\
a \\
0\end{array}$ & $\frac{n}{\hat{a}}$ \\
\hline$\stackrel{\infty}{8}$ & $\begin{array}{l}\Xi \\
\bar{\Xi} \\
\dot{\theta}\end{array}$ & $\begin{array}{l}\vec{n} \\
2 \\
- \\
-1\end{array}$ & $\begin{array}{l}\bar{\sigma} \\
\text { oे } \\
-\end{array}$ & $\begin{array}{l}\hat{n} \\
\infty \\
\hat{0} \\
0\end{array}$ & \begin{tabular}{l}
0 \\
$ٌ$ \\
$\varrho$ \\
\hdashline
\end{tabular} &  & 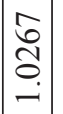 & 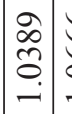 & \begin{tabular}{l}
0 \\
0 \\
0 \\
0 \\
\hdashline
\end{tabular} & $\begin{array}{c}\sigma \\
\sigma \\
0 \\
-\end{array}$ & 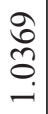 & 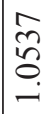 \\
\hline 홍 & $\begin{array}{l}n \\
0 \\
= \\
=\end{array}$ & $\begin{array}{l}2 \\
\text { రे } \\
\infty \\
0\end{array}$ & $\begin{array}{l}n \\
\infty \\
2 \\
o \\
0\end{array}$ & $\begin{array}{l}\hat{b} \\
\infty \\
=\end{array}$ & $\begin{array}{l}2 \\
\infty \\
0 \\
\infty \\
0 \\
0\end{array}$ & $\begin{array}{c}\overrightarrow{\bar{r}} \\
\hat{\sigma} \\
\dot{-}\end{array}$ & 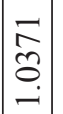 & $\mid$\begin{tabular}{c|} 
\pm \\
$\dot{+}$ \\
$\dot{0}$ \\
$\dot{0}$
\end{tabular} & $\begin{array}{l}2 \\
\dot{\partial} \\
\infty \\
\infty \\
0\end{array}$ & $\begin{array}{c}\hat{\sigma} \\
\stackrel{2}{J} \\
-\end{array}$ & $\begin{array}{c}\mathscr{2} \\
\underset{0}{\infty} \\
0 \\
0\end{array}$ & $\begin{array}{l}0 \\
\hat{N} \\
0 \\
\hat{0} \\
0\end{array}$ \\
\hline ¿̊̊ & $\begin{array}{c}\sim \\
\tilde{n} \\
0 \\
-\end{array}$ & 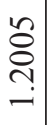 & 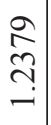 & $\begin{array}{l}\hat{\hat{N}} \\
\hat{\sigma}\end{array}$ & $\frac{\mathfrak{a}}{\stackrel{n}{-}}$ & $\begin{array}{l}\tilde{\Xi} \\
\check{\Xi} \\
-\end{array}$ & $\begin{array}{c}\dot{J} \\
\dot{+} \\
\\
-\end{array}$ & $\stackrel{n}{\stackrel{n}{二}}$ & 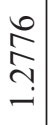 & $\left|\begin{array}{l}\infty \\
n \\
n \\
0 \\
-\end{array}\right|$ & \begin{tabular}{l}
\multirow{J}{0}{} \\
0 \\
$ت$ \\
-
\end{tabular} & $\frac{n}{\stackrel{n}{n}}$ \\
\hline$\stackrel{n}{\stackrel{\overbrace{}}{8}}$ & $\begin{array}{l}\infty \\
\sim \\
\\
\end{array}$ & $\begin{array}{l}\hat{\sigma} \\
\hat{n} \\
\infty \\
0\end{array}$ & $\begin{array}{c}n \\
n \\
0 \\
0\end{array}$ & \begin{tabular}{l}
0 \\
2 \\
\hdashline \\
\end{tabular} & 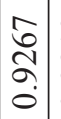 & $\begin{array}{c}a \\
\infty \\
a \\
0\end{array}$ & ָָ & $\begin{array}{l}\underset{\sim}{+} \\
\tilde{D} \\
\infty \\
\dot{0}\end{array}$ & $\begin{array}{l}\infty \\
\infty \\
2 \\
0 \\
-\end{array}$ & $\frac{n}{m}$ & $\begin{array}{l}n \\
\tilde{n} \\
\infty \\
0 \\
\dot{0}\end{array}$ & 응 \\
\hline ষ্ণ & 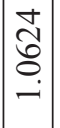 & $\begin{array}{c}0 \\
\vec{G} \\
0 \\
- \\
-1\end{array}$ & $\begin{array}{l}0 \\
\text { O } \\
0 \\
0\end{array}$ & $\underset{\dot{O}}{\overrightarrow{0}}$ & $\begin{array}{l}a \\
n \\
0 \\
-1\end{array}$ & $\begin{array}{c}\hat{\sigma} \\
\hat{n} \\
0 \\
-1\end{array}$ & $\mid \begin{array}{l}0 \\
\bar{a} \\
\dot{2} \\
-1\end{array}$ & $\stackrel{\alpha}{\sigma}$ & $\begin{array}{l}\cong \\
\Xi \\
\Xi\end{array}$ &  & $\begin{array}{l}\frac{1}{\sigma} \\
\hat{\sigma}\end{array}$ & $\stackrel{n}{8}$ \\
\hline 至 & 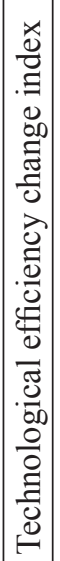 &  & 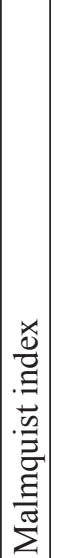 & 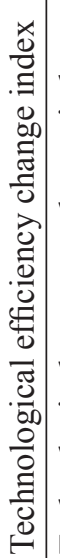 & 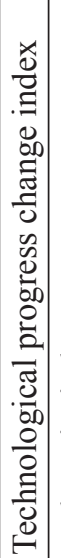 & 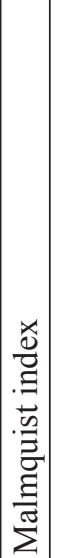 & 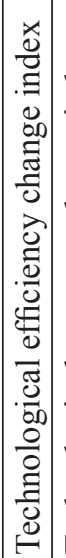 & 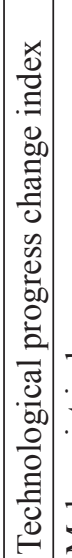 & 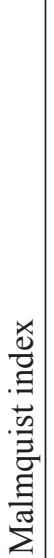 & 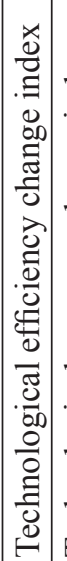 & 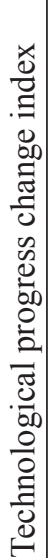 & 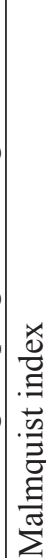 \\
\hline 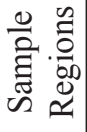 & & 吾 & & \multicolumn{3}{|c|}{ 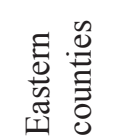 } & \multicolumn{3}{|c|}{ 矛 } & \multicolumn{3}{|c|}{ 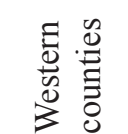 } \\
\hline
\end{tabular}


Wang Zhenhua, Zhang Guangsheng • Industrial policy, production efficiency improvement...

0
0
0
0
0
0
0
0
0
0
0
0
0
0
0
0

\begin{tabular}{|c|c|c|c|c|c|c|c|c|c|c|c|c|c|c|c|c|c|c|}
\hline \multicolumn{6}{|c|}{  } & \multicolumn{6}{|c|}{ 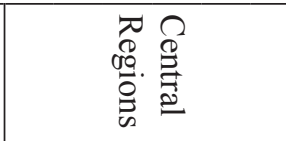 } & \multicolumn{6}{|c|}{ 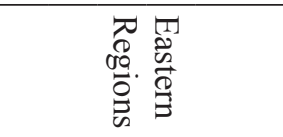 } & \\
\hline 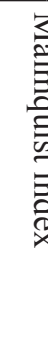 & 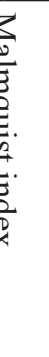 & 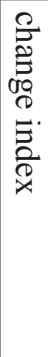 & 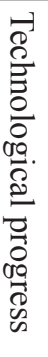 & 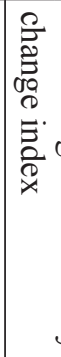 & 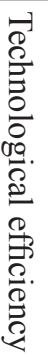 & 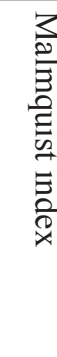 & & 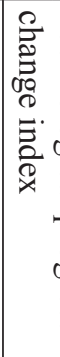 & 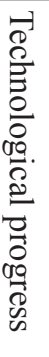 & 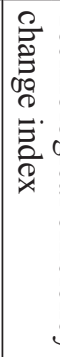 & 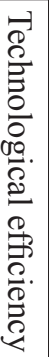 & 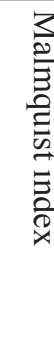 & & 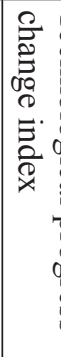 & 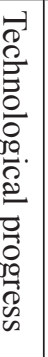 & 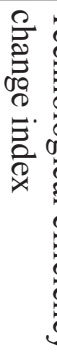 & 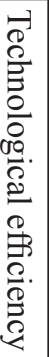 & \\
\hline 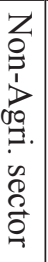 & 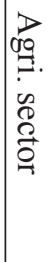 & 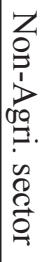 & 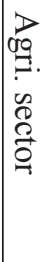 & 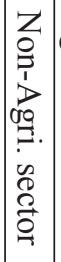 & 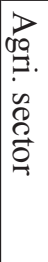 & 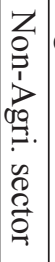 & 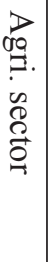 & 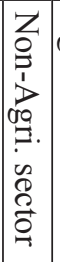 & 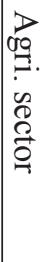 & 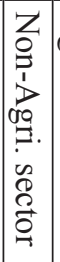 & 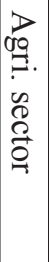 & 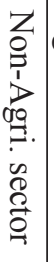 & 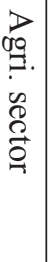 & 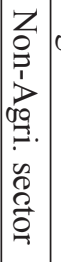 & 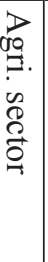 & 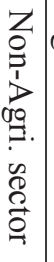 & 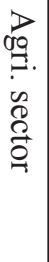 & \\
\hline $\begin{array}{l}\dot{0} \\
\dot{\infty} \\
\dot{v}\end{array}$ & 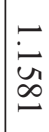 & $\frac{\varpi}{\infty}$ & $\underset{\varpi}{\check{D}}$ & $\begin{array}{l}0 \\
0 \\
0 \\
0 \\
0 \\
0\end{array}$ & $\begin{array}{l}0 \\
0 \\
\infty \\
\infty \\
0 \\
0\end{array}$ & $\begin{array}{l}\stackrel{0}{0} \\
\stackrel{0}{0} \\
9 \\
+\end{array}$ & 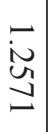 & $\begin{array}{l}-\dot{0} \\
\dot{\infty} \\
\infty \\
\sim\end{array}$ & $\begin{array}{l}-\tilde{w} \\
w \\
w\end{array}$ & $\begin{array}{l}0 \\
\dot{6} \\
\omega \\
u \\
u\end{array}$ & $\frac{1}{0}$ & $\begin{array}{l}\dot{1} \\
\dot{8} \\
\dot{u}\end{array}$ & 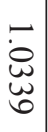 & $\mid \begin{array}{l}0 \\
\dot{0} \\
u \\
w \\
\sigma\end{array}$ & 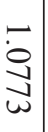 & $\begin{array}{l}- \\
\dot{0} \\
\dot{n ̆} \\
\dot{u}\end{array}$ & $\begin{array}{l}0 \\
\text { ơ } \\
\text { un } \\
\text { v }\end{array}$ & 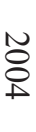 \\
\hline $\begin{array}{l}0 \\
i \\
0 \\
\mathbb{1}\end{array}$ & $\begin{array}{l}\dot{0}_{0} \\
\dot{0}\end{array}$ & $\begin{array}{l}0 \\
\infty \\
0 \\
0 \\
0 \\
y\end{array}$ & lo & $\begin{array}{l}- \\
w \\
\infty \\
\infty\end{array}$ & $\begin{array}{l}- \\
0 \\
0 \\
\dot{1}\end{array}$ & 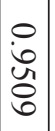 & 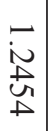 & $\begin{array}{l}0 \\
\dot{0} \\
\tilde{n} \\
\sigma\end{array}$ & $\stackrel{-}{\stackrel{\sim}{0}}$ & $\mid \begin{array}{l}-\dot{0} \\
\dot{\infty} \\
\infty \\
\sigma\end{array}$ & $\begin{array}{l}-\dot{0} \\
N \\
\infty \\
\sigma\end{array}$ & $\begin{array}{l}\stackrel{0}{0} \\
\dot{0} \\
\infty \\
\infty\end{array}$ & $\begin{array}{l}0 \\
\dot{0} \\
\circ \\
0 \\
\text { ur }\end{array}$ & $\begin{array}{l}0 \\
6 \\
\infty \\
\infty\end{array}$ & 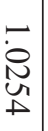 & 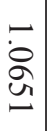 & $\begin{array}{l}0 \\
\text { ட̊ } \\
2 \\
8\end{array}$ & 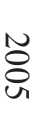 \\
\hline $\begin{array}{l}- \\
\dot{0} \\
\text { y̦ }\end{array}$ & $\begin{array}{l}\dot{j} \\
\dot{y} \\
\text { y্ }\end{array}$ & 泣 & 효 & $\left|\begin{array}{l}0 \\
\infty \\
0 \\
\mathfrak{\sigma} \\
-1\end{array}\right|$ & 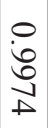 & $\begin{array}{l}\vec{\sigma} \\
\vec{v} \\
\vec{u}\end{array}$ & $\begin{array}{l}-\dot{\infty} \\
\dot{\phi} \\
\dot{\phi}\end{array}$ & $\begin{array}{l}-\dot{0} \\
\dot{0} \\
\infty \\
0\end{array}$ & $\begin{array}{l}-\dot{0} \\
\text { ஓे } \\
\infty \\
\alpha\end{array}$ & 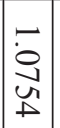 & 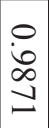 & $\frac{-}{\circ}$ & $\begin{array}{l}\dot{0} \\
\infty \\
0\end{array}$ & $\begin{array}{l}-\dot{0} \\
\dot{w} \\
\tilde{\omega}\end{array}$ & 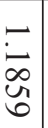 & $\begin{array}{l}\circ \\
\dot{0} \\
\infty \\
\infty\end{array}$ & $\begin{array}{l}0 \\
\stackrel{0}{*} \\
\pm \\
\pm\end{array}$ & $\begin{array}{l}\text { \& } \\
8\end{array}$ \\
\hline 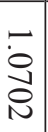 & $\begin{array}{l}\dot{0} \\
\dot{n} \\
\vec{N}\end{array}$ & $\begin{array}{l}0 \\
\dot{0} \\
\omega \\
0 \\
0\end{array}$ & 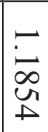 & 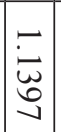 & $\begin{array}{l}0 \\
\infty \\
\infty \\
\infty \\
\infty\end{array}$ & $\begin{array}{l}\bar{\omega} \\
\dot{\omega} \\
\check{\alpha}\end{array}$ & 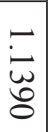 & $\mid \begin{array}{l}-\dot{0} \\
\stackrel{+}{ \pm} \\
0\end{array}$ & $\frac{\sim}{\stackrel{\sim}{\sim}}$ & $\begin{array}{l}\dot{0} \\
\infty \\
+ \\
0\end{array}$ & $\begin{array}{l}0 \\
\dot{0} \\
w \\
u \\
u\end{array}$ & 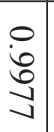 & $\begin{array}{l}0 \\
\dot{0} \\
w \\
w \\
0\end{array}$ & $\begin{array}{l}0 \\
\text { io } \\
\text { Ŵ } \\
\infty\end{array}$ & $\begin{array}{l}0 \\
\dot{0} \\
+\infty \\
\infty\end{array}$ & 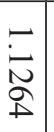 & $\begin{array}{l}0 \\
i \\
\infty \\
w \\
\omega\end{array}$ & 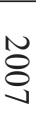 \\
\hline$\underset{+\infty}{\stackrel{\infty}{\infty}}$ & $\begin{array}{l}0 \\
\dot{\infty} \\
\infty \\
\infty \\
y\end{array}$ & 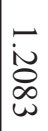 & $\begin{array}{l}0 \\
\infty \\
0 \\
\text { L̆ } \\
\sigma\end{array}$ & $\left|\begin{array}{l}0 \\
i \\
\text { J } \\
\text { J }\end{array}\right|$ & 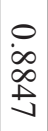 & 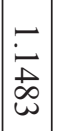 &  & $\begin{array}{l}- \\
\dot{\sigma} \\
\curvearrowright \\
\infty\end{array}$ & $\frac{\sim}{\stackrel{N}{N}}$ & $\mid \begin{array}{l}0 \\
\text { io } \\
\text { U్ } \\
\text { un }\end{array}$ & $\begin{array}{l}0 \\
0 \\
\dot{v} \\
u \\
u\end{array}$ & 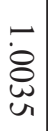 & $\begin{array}{l}0 \\
\stackrel{0}{0} \\
\infty \\
\infty\end{array}$ & $\begin{array}{l}0 \\
\text { io } \\
\text { un } \\
\omega\end{array}$ & 官 & $\begin{array}{l}-\tilde{0} \\
\tilde{0} \\
\infty \\
0\end{array}$ & $\begin{array}{l}0 \\
\infty \\
\infty \\
\stackrel{0}{+} \\
\perp\end{array}$ & $\underset{\infty}{\stackrel{\infty}{8}}$ \\
\hline $\begin{array}{l}-\dot{0} \\
\underset{\mathbf{J}}{0}\end{array}$ & $\stackrel{\dot{0}}{\circ}$ & $\begin{array}{l}0 \\
\infty \\
\infty \\
0 \\
0\end{array}$ & $\underset{\sim}{\stackrel{\sim}{\sigma}}$ & $\begin{array}{l}-\dot{v} \\
\dot{v} \\
\dot{y}\end{array}$ & $\begin{array}{l}0 \\
\infty \\
w \\
\omega \\
\sigma\end{array}$ & $\left|\begin{array}{l}-\overrightarrow{0} \\
\dot{0} \\
\tilde{n} \\
u\end{array}\right|$ & $\begin{array}{l}0 \\
\infty \\
0 \\
N \\
N\end{array}$ & \begin{tabular}{|l|}
0 \\
$\infty$ \\
$\infty$ \\
$\infty$ \\
$w$ \\
$v$
\end{tabular} & $\stackrel{-}{\sim}$ & $\begin{array}{l}\vec{\omega} \\
\tilde{\omega} \\
\tilde{\omega}\end{array}$ & $\begin{array}{l}0 \\
\stackrel{v}{0} \\
\text { w } \\
\omega\end{array}$ & $\begin{array}{l}0 \\
\dot{\circ} \\
\stackrel{0}{0} \\
\stackrel{0}{0}\end{array}$ & $\begin{array}{c}\cdot \\
\dot{\omega} \\
\dot{\omega}\end{array}$ & $\begin{array}{l}0 \\
\dot{8} \\
8 \\
8 \\
8\end{array}$ & $\underset{N}{N}$ & $\begin{array}{l}0 \\
\stackrel{0}{0} \\
\dot{\infty} \\
\infty \\
\end{array}$ & $\begin{array}{l}0 \\
\dot{0} \\
\dot{1} \\
a\end{array}$ & $\begin{array}{l}\text { } \\
8 \\
8\end{array}$ \\
\hline $\begin{array}{l}0 \\
\text { o } \\
\text { 을 }\end{array}$ & $\begin{array}{l}\text { 웅 } \\
\text { مे }\end{array}$ & $\begin{array}{l}- \\
0 \\
\infty \\
0 \\
\text { ur }\end{array}$ & $\begin{array}{l}0 \\
\infty \\
\infty \\
\infty \\
0\end{array}$ & $\left|\begin{array}{l}0 \\
\infty \\
\infty \\
0 \\
0 \\
0\end{array}\right|$ & 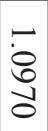 & $\mid \begin{array}{l}0 \\
\dot{0} \\
\stackrel{1}{0} \\
0\end{array}$ & $\begin{array}{l}\dot{0} \\
\dot{y} \\
\dot{v}\end{array}$ & $\left|\begin{array}{l}0 \\
0 \\
0 \\
0 \\
0\end{array}\right|$ & $\begin{array}{l}0 \\
\dot{0} \\
0 \\
\omega \\
\omega\end{array}$ & $\mid \begin{array}{l}- \\
0 \\
N \\
\tilde{N}\end{array}$ & 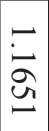 & $\begin{array}{l}-\dot{0} \\
\stackrel{+}{\not} \\
+\end{array}$ & $\begin{array}{c}\dot{\omega}_{\omega} \\
\bar{N}\end{array}$ & $\begin{array}{l}0 \\
0 \\
0 \\
0 \\
10\end{array}$ & $\begin{array}{l}\underset{0}{0} \\
\text { ư }\end{array}$ & $\begin{array}{l}0 \\
\text { ర్ } \\
0 \\
\infty\end{array}$ & $\begin{array}{l}-\dot{0} \\
\dot{\$} \\
\infty\end{array}$ & $\begin{array}{l}\stackrel{\widetilde{O}}{0} \\
0\end{array}$ \\
\hline $\begin{array}{l}\dot{0} \\
\stackrel{+}{ \pm} \\
u\end{array}$ & $\begin{array}{l}\dot{0} \\
\stackrel{+}{\mathbf{N}}\end{array}$ & $\frac{\dot{\omega}}{\dot{\omega}}$ & 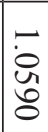 & $\left|\begin{array}{l}\overrightarrow{0} \\
\dot{+} \\
\text { v }\end{array}\right|$ & $\begin{array}{l}\circ \\
\dot{0} \\
9 \\
\text { y }\end{array}$ & $\begin{array}{l}\overrightarrow{0} \\
\dot{y} \\
\vec{\omega}\end{array}$ & 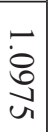 & $\begin{array}{l}-\dot{0} \\
\stackrel{0}{N}\end{array}$ & $\begin{array}{l}\stackrel{\sim}{\sim} \\
\stackrel{\infty}{\infty}\end{array}$ & $\mid \begin{array}{l}\overrightarrow{0} \\
\stackrel{+}{0} \\
\infty\end{array}$ & $\begin{array}{l}0 \\
\text { jo } \\
\text { Ja }\end{array}$ & $\begin{array}{l}\dot{8} \\
\text { 응 }\end{array}$ & $\begin{array}{l}\dot{0} \\
\dot{+} \\
+\infty\end{array}$ & $\begin{array}{l}0 \\
\text { io } \\
\text { a } \\
=\end{array}$ & $\begin{array}{l}\dot{0} \\
\stackrel{8}{a}\end{array}$ & 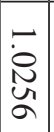 & $\begin{array}{l}0 \\
0 \\
0 \\
\text { L } \\
-1\end{array}$ & \\
\hline
\end{tabular}

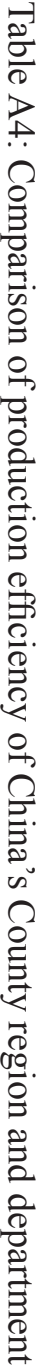

